\title{
Shape Changes, Exocytosis, and Cytosolic Free Calcium Changes in Stimulated Human Eosinophils
}

\author{
Peter Kernen," Matthias P. Wymann, ${ }^{*}$ Vinzenz von Tscharner, ${ }^{*}$ David A. Deranleau, ${ }^{*}$ Po-Chun Tai, ${ }^{+t}$ \\ Christopher J. Spry, ${ }^{\star}$ Clemens A. Dahinden," and Marco Baggiolini* \\ From the *Theodor-Kocher Institute, University of Bern, CH-3000 Bern 9, Switzerland; the ${ }^{\ddagger}$ Department of Cellular \\ and Molecular Sciences, St. George's Hospital Medical School, Cranmer Terrace, London SWI7 ORE; and the \\ ${ }^{8}$ Institute of Clinical Immunology, Inselspital, CH-3010 Bern, Switzerland
}

\begin{abstract}
Essentially pure preparations of normal density eosinophils obtained from patients with hypereosinophilic syndrome (HES) were stimulated with complement factor $5 \mathbf{a}(\mathbf{C 5 a})$, platelet-activating factor (PAF), FMLP and neutrophil-activating peptide (NAP-1/IL-8). Three responses were studied, the transient rise in cytosolic free calcium concentration $\left(\left[\mathrm{Ca}^{2+} \mathrm{h}\right)\right.$ (derived from indo-1 fluorescence), shape changes (measured by laser turbidimetry), and exocytosis of eosinophil peroxidase (EPO) (assessed by $\mathrm{H}_{2} \mathrm{O}_{2}$ /luminol-dependent chemiluminescence). Responses were obtained with all four agonists, but C5a and PAF were by far more potent than FMLP and NAP-1/IL-8, which induced only minor effects. Pretreatment of the cells with pertussis toxin attenuated $\left[\mathrm{Ca}^{2+}\right]_{i}$ changes, EPO release and, to a lesser extent, shape changes, indicating that GTP-binding proteins of $G_{1}-$ type are involved in receptor-dependent signal transduction processes leading to these responses. A clear dissociation was observed in the control of the shape change response and EPO exocytosis. The shape change was not affected by $\mathrm{Ca}^{2+}$ depletion or treatment with the protein kinase inhibitor staurosporine, but exocytosis was prevented by $\mathrm{Ca}^{2+}$ depletion and markedly enhanced by staurosporine. The activation of the contractile system, leading to shape changes and motility, thus appears to be independent of the classical signal transduction pathway involving phospholipase $\mathrm{C}$, a $\left[\mathrm{Ca}^{2+}\right]$ rise and protein kinase $\mathrm{C}$ activation. Exocytosis is, as expected, $\mathrm{Ca}^{2+}$ dependent and appears to be under a negative control involving protein phosphorylations. (J. Clin. Invest. 1991. 87:2012-2017.) Key words: signal transduction • hypereosinophilic syndrome • turbidimetry • calcium depletion • staurosporine
\end{abstract}

\section{Introduction}

Eosinophils are specialized proinflammatory cells found in the blood and tissues that play an important role in host defence and disease (1-3). They increase in number and become activated in a variety of parasitic, allergic, and inflammatory disorders (4), and respond to different stimuli by a selective release

\footnotetext{
${ }^{\dagger}$ Deceased.

Address correspondence and reprint requests to Dr. Marco Baggliolini, Theodor-Kocher Institute, University of Bern, CH-3012 Bern, Switzerland. 1991.

Received for publication 2 May 1990 and in revised form 4 February

J. Clin. Invest.

(c) The American Society for Clinical Investigation, Inc.

$0021-9738 / 91 / 06 / 2012 / 06 \$ 2.00$

Volume 87, June 1991, 2012-2017
}

of their granule proteins (5). The cDNA encoding four highly basic and cytotoxic granule proteins: eosinophil cationic protein, eosinophil-derived neurotoxin, eosinophil peroxidase (EPO) ${ }^{1}$, and major basic protein, have recently been cloned and sequenced (6-9). The cytokines IL-3, IL-5, and granulocyte-macrophage colony-stimulating factor (GM-CSF), which control eosinophil differentiation, activation, and secretion have also been characterized, cloned, and sequenced (10). Despite this rapidly advancing knowledge in the molecular and cellular biology of the eosinophils, little is known about the transmembrane signaling pathways that transmit information from the outside to the cell interior as a result of agonist-receptor interaction. Eosinophils share several properties with other granulocytes, neutrophils in particular, as they perform chemotaxis and phagocytosis, and secrete granular contents into phagocytic vacuoles and the extracellular medium $(11,12)$. Some of the biochemical mechanisms involved in signal transduction pathways activated by receptor-agonist binding have been described in neutrophils (13-18). It is not clear whether eosinophil responses are dependent on signal transduction mechanisms similar to those found in neutrophils.

We have now studied some of the postreceptor events leading to shape changes and EPO secretion in human blood eosinophils from patients with the hypereosinophilic syndrome (HES), stimulated with complement factor 5a (C5a), plateletactivating factor (PAF), FMLP, or neutrophil-activating peptide (NAP-1)/IL-8. Pertussis toxin prevented EPO exocytosis and the cytosolic free calcium concentration $\left(\left[\mathrm{Ca}^{2+}\right]_{i}\right)$ changes, but inhibited the shape changes only in part, suggesting a different regulation of these responses. Again in contrast to exocytosis, the shape change was independent of $\mathrm{Ca}^{2+}$ and thus appears to be dissociated from the classical signal transduction pathway involving phospholipase $\mathrm{C}$ and protein kinase $\mathrm{C}$.

\section{Methods}

Materials. Materials were purchased from sources described elsewhere (18) except for staurosporine (Fluka AG, Buchs, Switzerland), Bordetella pertussis toxin (List Biological Laboratories Inc., Campbell, CA), and indo-1/acetoxymethylester (AM) (Molecular Probes, Eugene, OR). Recombinant NAP-1/IL-8 was obtained from the Sandoz Research Institute, Vienna, Austria (19), and recombinant human GMCSF (batch No. 860107.00) from Sandoz Ltd., Basel, Switzerland. C5a was prepared as described by Hugli et al. (20).

Solutions. Experiments were carried out in a test buffer containing $130 \mathrm{mM} \mathrm{NaCl}, 5.0 \mathrm{mM} \mathrm{NaHCO}_{3}, 4.6 \mathrm{mM} \mathrm{KCl}, 5 \mathrm{mM}$ glucose, $1 \mathrm{mM}$

1. Abbreviations used in this paper: $\left[\mathrm{Ca}^{2+}\right]_{\mathrm{i}}$, cytosolic free calcium; $\mathrm{C} 5 \mathrm{a}$, complement factor 5a; EPO, eosinophil peroxidase; HES, hypereosinophilic syndrome; NAP, neutrophil-activating peptide; PAF, platelet-activating factor. 
$\mathrm{CaCl}_{2}$, and $20 \mathrm{mM} \mathrm{4-(2-hydroxyethyl)-piperazine-1-ethanesulfonate}$ (Hepes) adjusted to $\mathrm{pH} 7.4$ with $\mathrm{NaOH}$. Phorbol 12-myristate 13-acetate (PMA), FMLP, staurosporine and indo-1/AM stock solutions were prepared in dimethylsulfoxide. C5a, NAP-1/IL-8, and PAF were diluted in PBS ( $137 \mathrm{mM} \mathrm{NaCl}, 2.7 \mathrm{mM} \mathrm{KCl}, 8.1 \mathrm{mM} \mathrm{Na}_{2} \mathrm{HPO}_{4}, 1.5 \mathrm{mM}$ $\mathrm{KH}_{2} \mathrm{PO}_{4}, \mathrm{pH} 7.4$ ) containing $2.5 \mathrm{mg} / \mathrm{ml} \mathrm{BSA}$

Cell preparation. Eosinophils from four patients with HES were purified from venous blood anticoagulated with $0.01 \mathrm{M}$ EDTA, by the method of Vadas et al. (21) with some modifications (22). Normal density eosinophils were collected from $24 \%$-metrizamide fractions with a purity of $\sim 90 \%$. The cells were washed twice in RPMI 1640, pH 7.2 (Flow Laboratories, Rickmansworth, UK), containing $30 \mathrm{mg} /$ liter of DNAse (Sigma Chemical Co., Poole, UK) and 2\% FCS(Flow Laboratories), resuspended in RPMI 1640 supplemented with 10\% FCS (5 $\left.\times 10^{6} / \mathrm{ml}\right)$, and cultured for $24-48 \mathrm{~h}\left(37^{\circ} \mathrm{C}, 5 \% \mathrm{CO}_{2}\right)$ in the presence or absence of $5 \mathrm{nM}$ GM-CSF. Cultured eosinophils were washed, resuspended in test buffer $\left(10^{7}\right.$ cells $\left./ \mathrm{ml}\right)$, and kept at $4-10^{\circ} \mathrm{C}$ until use. All assays were performed at $37^{\circ} \mathrm{C}$ in the presence of $1 \mathrm{mM} \mathrm{Ca}^{2+}$ if not stated otherwise. Each experiment was performed at least four times on two or more different eosinophil preparations.

Eosinophil viability. The time required for obtaining the blood samples and for purification of the cells made it necessary to keep purified eosinophils overnight before testing. Under the culture conditions described above, the responsiveness of the cells remained qualitatively unaltered and decreased only slightly in amplitude. GM-CSF prolonged cell survival in culture as judged by trypan blue exclusion. In addition, overnight culture was an efficient way to eliminate contaminating neutrophils and to improve the purity of the preparations, which rose from $\sim 90 \%$ to over $96 \%$. The presence of GM-CSF did not appreciably affect the kinetics of the $\left[\mathrm{Ca}^{2+}\right]_{i}$ rise, shape change, and EPO release induced by C5a, PAF, FMLP, or NAP-1/IL-8.

Shape and cytosolic free $\mathrm{Ca}^{2+}$ changes. Shape changes were assessed by turbidimetry as described for neutrophils by Wymann et al. (23). Real-time changes in $\left[\mathrm{Ca}^{2+}\right]_{i}$ were measured in an optical multichannel analyzer (24) using the fluorescent calcium indicator indo-1 (25). Indicator loading was performed by incubating $10^{7}$ eosinophils in $1 \mathrm{ml}$ of test buffer with $3 \mu \mathrm{M}$ indo-1/AM for $25 \mathrm{~min}$ at $37^{\circ} \mathrm{C}$. After washing, loaded cells were resuspended at a concentration of $8 \times 10^{5} / \mathrm{ml}$. Fluorescence was excited by the 350.7- and 356.4-nm emission lines of a tunable krypton ion laser, and the $\left[\mathrm{Ca}^{2+}\right]_{i}$ was calculated on the basis of the ratio of the integrated fluorescence intensities $(R)$ between $400-410 \mathrm{~nm}$ and $475-485 \mathrm{~nm}$ using the formula (25):

$$
\left[\mathrm{Ca}^{2+}\right]_{\mathrm{i}}=K_{\mathrm{d}}\left[\frac{R-R_{\min }}{R_{\max }-R}\right]\left[\frac{S_{\mathrm{p}}}{S_{\mathrm{b} 2}}\right]
$$

$R_{\min }\left(4.03 \times 10^{-2}\right)$ and $R_{\max }(1.00)$ are the fluorescence ratios of free and $\mathrm{Ca}^{2+}$ saturated indicator. The instrument-dependent ratio $S_{\mathrm{b} 2} / S_{\mathrm{b} 2}$ was determined from the fluorescence intensities of the free and $\mathrm{Ca}^{2+}$ saturated indicator at $480 \mathrm{~nm}$ and was found to be 2.24 .

$\mathrm{Ca}^{2+}$ depleted eosinophils were obtained by incubating $10^{7}$ cells $/ \mathrm{ml}$ with $10 \mu \mathrm{M}$ of the $\mathrm{Ca}^{2+}$ chelator quin2/AM in test medium containing $2 \mathrm{mM}$ EGTA instead of $1 \mathrm{mM} \mathrm{Ca}^{2+}$ for $30 \mathrm{~min}$ at $37^{\circ} \mathrm{C}$.

$B$. pertussis toxin treatment was performed by incubation of 1 $\times 10^{7}$ eosinophils $/ \mathrm{ml}$ for $90 \mathrm{~min}$ at $37^{\circ} \mathrm{C}$ with and without $2 \mu \mathrm{g} / \mathrm{ml}$ pertussis toxin. The cells were then washed and resuspended in test medium.

Exocytosis. The release of EPO was measured by luminol-dependent chemiluminescence using a modification of the method of Carlson et al. (26). Suspensions of $2 \times 10^{5}$ eosinophils were preincubated for $4 \mathrm{~min}$ at $37^{\circ} \mathrm{C}$ in $1 \mathrm{ml}$ of test buffer supplemented with $100 \mu \mathrm{M}$ luminol, $200 \mu \mathrm{M} \mathrm{H}_{2} \mathrm{O}_{2}$, and $5 \mu \mathrm{g}$ of cytochalasin $\mathrm{B}$ and then stimulated by agonist addition. No release of EPO was observed in the absence of cytochalasin B. Emitted light, proportional to the total amount of released EPO, was digitally recorded at time intervals of $200 \mathrm{~ms}$. The proportionality between emitted light and released EPO is progressively lost by inactivation of the peroxidase, e.g., by dimerization (27). This assay was therefore used for assessing the onset time and the initial time course of release only.

\section{Results}

Effects of different stimuli. All four agonists used elicited a rise in $\left[\mathrm{Ca}^{2+}\right]_{\mathrm{i}}$ which increased from resting levels of $120-150 \mathrm{nM}$ to 500-1,000 nM after stimulation with PAF or C5a, but only to 180-300 nM after stimulation with FMLP or NAP-1/IL-8 (Fig. 1). A similar pattern of responses is shown by the recordings of shape-sensitive light transmission changes induced by maximum effective agonist concentrations. Marked increases of $2-3 \%$ in suspension transmission were induced by C5a or PAF, and much lesser ones by FMLP and NAP-1/IL-8 (Fig. 2). $\left[\mathrm{Ca}^{2+}\right]_{\mathrm{i}}$ and transmission changes were rapid and transient and reached a maximum within 5 and $10 \mathrm{~s}$, respectively, and in either case the total duration of the response was $\sim 1 \mathrm{~min}$. As shown by the tracings in Fig. 3, the four agonists also induced EPO release with an onset time of 2-3 s. C5a was the most effective stimulus, followed by PAF, which was about onefourth as potent, and by FMLP. In comparison to C5a the response to NAP-1/IL-8 was almost negligible.

Effect of $B$. pertussis toxin. Pretreatment of the eosinophils with pertussis toxin inhibited the C5a-induced release of EPO and $\left[\mathrm{Ca}^{2+}\right]_{\mathrm{i}}$ rises by more than 90 and $95 \%$, respectively (Fig. 4 , top and middle). Under identical conditions, however, the changes in light transmission were reduced by only $\sim 75 \%$ compared with control experiments (Fig. 4, bottom). PAF-mediated responses showed the same behavior in pertussis toxinpretreated cells as those induced by C5a.

Role of $\left[\mathrm{Ca}^{2+}\right]_{i}$. Depletion of storage pool $\mathrm{Ca}^{2+}$ by loading the eosinophils with an excess of Quin 2 in the presence of EGTA (see Methods) virtually precluded $\left[\mathrm{Ca}^{2+}\right]_{\mathrm{i}}$ changes. As shown in Fig. 5, normal and $\mathrm{Ca}^{2+}$ depleted eosinophils showed similar shape changes in response to PAF although no rise in $\left[\mathrm{Ca}^{2+}\right]_{i}$ was observed in $\mathrm{Ca}^{2+}$ depleted cells. A similar set of responses was obtained upon stimulation with $\mathrm{C} 5 \mathrm{a}$ instead of PAF. Neither agonist, however, could elicit any measurable EPO release in $\mathrm{Ca}^{2+}$ depleted eosinophils (data not shown).

Effect of staurosporine. At concentrations that inhibit PMA-dependent protein phosphorylation and the respiratory burst in human neutrophils (28) and the respiratory burst in eosinophils (Wymann et al., manuscript in preparation), staurosporine doubled the total amount of EPO released from eosinophils without affecting the time course of the response

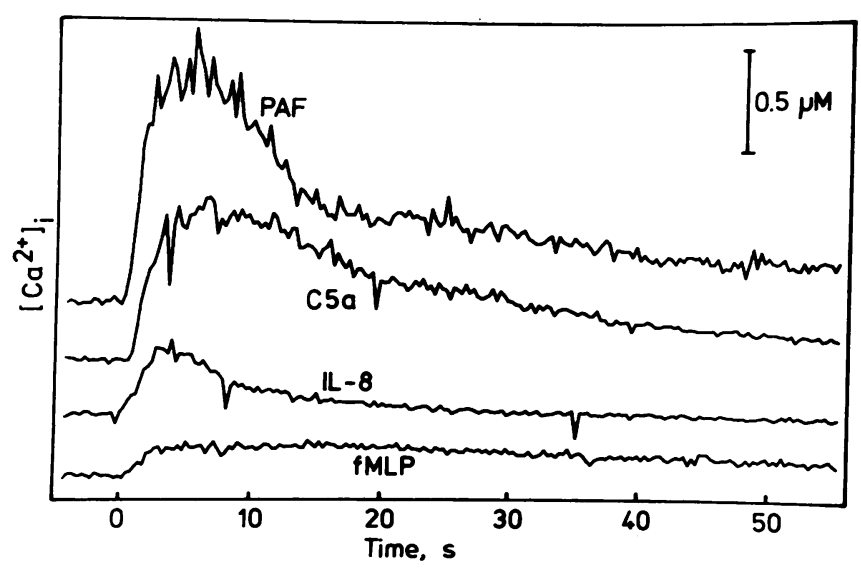

Figure 1. $\left[\mathrm{Ca}^{2+}\right]_{\mathrm{i}}$ changes of eosinophil suspensions $\left(8 \times 10^{5}\right.$ cells $\left./ \mathrm{ml}\right)$ stimulated at time zero by maximum effective agonist concentrations (10 nM C5a, 100 nM PAF, NAP-1/IL-8, or FMLP. The tracings are displaced along the ordinate for better readability. Initial $\left[\mathrm{Ca}^{2+}\right]_{\mathrm{i}}$ levels were between 120 and $150 \mathrm{nM}$. 


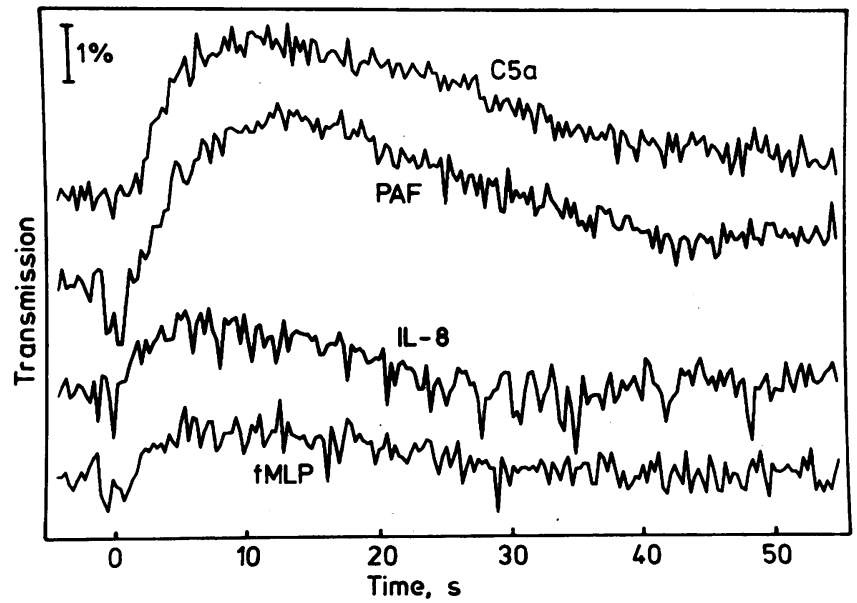

Figure 2. Light transmission changes of eosinophil suspensions (8 $\times 10^{5}$ cells $/ \mathrm{ml}$ ) stimulated at time zero by maximum effective agonist concentrations (10 nM C5a, 100 nM PAF, NAP-1/IL-8 or FMLP).

The tracings are displaced along the ordinate for better readability.

The initial transmission values were between 15 and $25 \%$, and the bar represents a relative transmission change of $1 \%$.

(Fig. 6). By contrast, under the same conditions, staurosporine did not alter the increase in light transmission that reflects shape changes (Fig. 6). A slight prolongation of this response was observed in the presence of the kinase inhibitor.

Effect of PMA. Preincubation of the eosinophil suspension with small amounts of PMA (1-10 nM) for 2 min reduced the extent of the $\left[\mathrm{Ca}^{2+}\right]_{i}$ changes induced by $\mathrm{C} 5 \mathrm{a}$ or PAF by $\sim 70 \%$ (Table I). Similar effects of PMA on receptor-dependent $\left[\mathrm{Ca}^{2+}\right]_{i}$ rises were also observed in human neutrophils $(29,30)$. Surprisingly, the effects on $\left[\mathrm{Ca}^{2+}\right]_{i}$ were paralleled by a decreased shape change response to PAF but not to C5a. PMA itself had no influence on the initial level of $\left[\mathrm{Ca}^{2+}\right]_{i}$ and changed the transmission by not more than $0.5 \%$. After $2 \mathrm{~min}$, before agonist stimulation, the transmission level again reached initial values. It is conceivable that the receptor-mediated shape change response can be affected differently depending on the agonist used. In neutrophils, for instance, pertussis toxin prevents the $\left[\mathrm{Ca}^{2+}\right]_{\mathrm{i}}$ rise induced by FMLP but only partially inhibits the one induced by PAF (31).

\section{Discussion}

The mechanism of activation of normal density human blood eosinophils obtained from hypereosinophilic individuals was

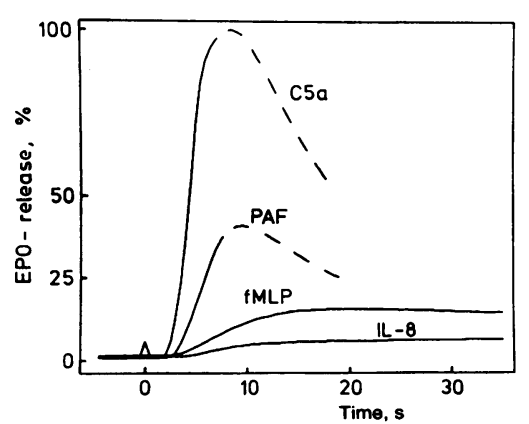

Figure 3. Release of EPO from eosinophil suspensions $\left(2 \times 10^{5}\right.$ cells/ml) stimulated at time zero by maximum effective agonist concentrations (10 nM C5a, 100 nM PAF, NAP-1/ IL-8, or FMLP). Luminol-dependent chemiluminescence recordings are shown relative to the change induced by $10 \mathrm{nM} \mathrm{C5a}$. The decrease following the apparent maxima reflect progressive inactivation of the released enzyme (see Methods).

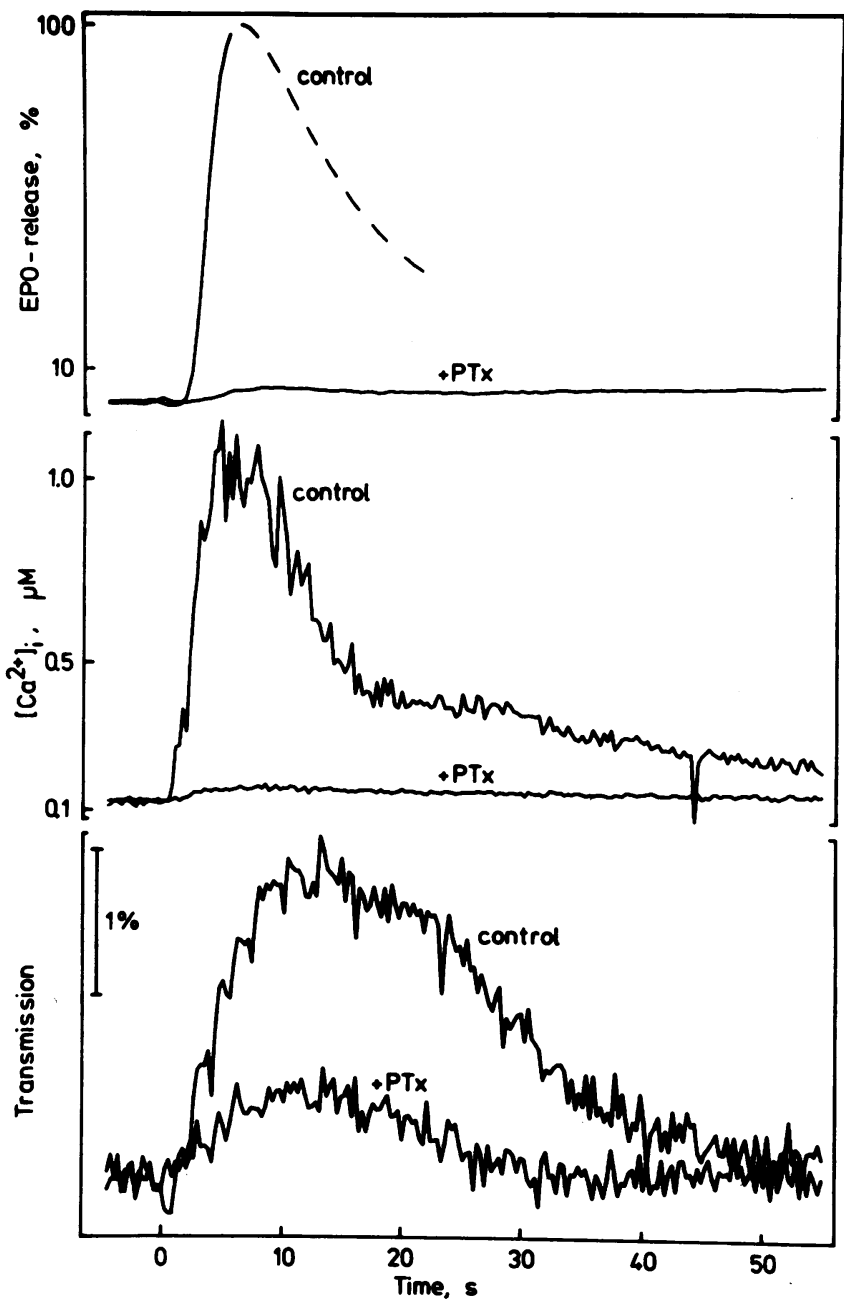

Figure 4. Effect of B. pertussis toxin treatment on the release of EPO (top), rise in $\left[\mathrm{Ca}^{2+}\right]_{\mathrm{i}}$ (middle), and light transmission changes (bottom). Eosinophils were incubated for $90 \mathrm{~min}$ at $37^{\circ} \mathrm{C}$ without (control) or with pertussis toxin $(P T x)$, washed, resuspended in test medium and stimulated with $10 \mathrm{nM}$ C5a. Similar results were obtained with 100 nM PAF.

studied on the basis of three responses, shape changes, exocytosis of EPO, and $\left[\mathrm{Ca}^{2+}\right]_{i}$ changes, using C5a, PAF, FMLP, and NAP-1/IL-8 as stimuli.

The shape change response, as measured by laser turbidimetry, probably reflects whole-cell shape changes associated with the activation of the intracellular motile apparatus (32, 33). Under physiological conditions, it is accompanied by a transient rise in $\left[\mathrm{Ca}^{2+}\right]_{i}$. The comparison of normal and $\mathrm{Ca}^{2+}$ depleted eosinophils, however, showed that shape changes do not require $\mathrm{Ca}^{2+}$ mobilization and are not appreciably affected by it. In this respect human eosinophils behaved like human neutrophils (34). In neutrophils, $\mathrm{Ca}^{2+}$ depletion prevents the formation of inositol trisphosphate, presumably through inactivation of the phosphatidylinositol-specific phospholipase $\mathrm{C}$ (35). Under these conditions the stimulus-dependent formation of filamentous actin remains unaffected (36), indicating that phospholipase $\mathrm{C}$ is not involved in the control of the motile response (34). According to these results, much the same conclusions can be drawn for eosinophils. In view of this similarity between the two cell types, it was surprising to observe that the shape change response induced in eosinophils by $\mathrm{C} 5 \mathrm{a}$ 


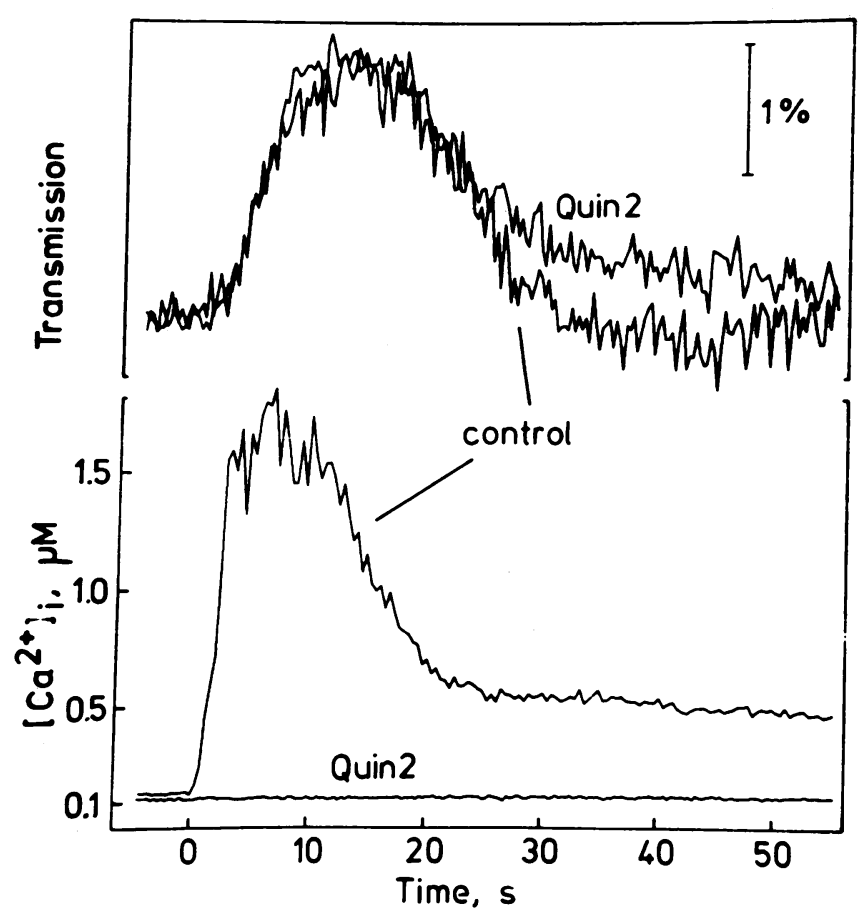

Figure 5. Effect of $\mathrm{Ca}^{2+}$ depletion on shape change. Normal (control) and $\mathrm{Ca}^{2+}$-depleted (Quin2) eosinophils were stimulated with $100 \mathrm{nM}$ PAF. Transmission (top) and $\left[\mathrm{Ca}^{2+}\right]_{\mathrm{i}}$ changes (bottom) are shown. Similar results were obtained with $10 \mathrm{nM}$ C5a.

and PAF was only partially inhibited by pertussis toxin. In human neutrophils, under otherwise identical conditions, half of the toxin concentration used in these experiments was sufficient to prevent the rise in $\left[\mathrm{Ca}^{2+}\right]_{i}$, the exocytosis of elastase, and the shape changes induced by chemotactic peptide agonists $(34,37)$, suggesting that the amount of toxin was sufficient for exhaustive ADP-ribosylation. On the basis of the susceptibility to pertussis toxin, Verghese et al. (31) suggested that agonistdependent $\left[\mathrm{Ca}^{2+}\right]_{\mathrm{i}}$ changes may be partly induced via a toxinresistant process when the bioactive lipids, $\mathrm{LTB}_{4}$ and PAF (in contrast to fMLP), are used as stimuli. Using PAF but not peptide agonists, we also observed only partial inhibition of shape and $\left[\mathrm{Ca}^{2+}\right]_{\mathrm{i}}$ changes by pertussis toxin pretreatment in human neutrophils (Kernen, P., unpublished results). These data clearly establish a role for pertussis toxin-inhibitable $G_{i \alpha}-$ proteins in the induction of eosinophil shape changes by stimulation with C5a or PAF. A more detailed study on the effects of pertussis toxin on eosinophil responses will be needed to elucidate a possible role of $\mathrm{G}$-proteins which are not available for ADP-ribosylation or other mechanisms bypassing $G_{i \alpha}$-proteins.

In contrast to the shape change response, exocytosis and the $\left[\mathrm{Ca}^{2+}\right]_{\mathrm{i}}$ rise were prevented by pertussis toxin and were dependent of intracellular $\mathrm{Ca}^{2+}$ mobilization. The transduction of agonist signals leading to either response appear, therefore, to be dependent on guanine nucleotide-binding regulatory proteins of the $G_{i}$ type and to require a transient elevation in $\left[\mathrm{Ca}^{2+}\right]_{i}$. These observations are in agreement with reports showing that exposure of guinea-pig eosinophils to EGTA-containing medium (which precludes $\mathrm{Ca}^{2+}$ entry and slowly depletes intracellular storage pool $\mathrm{Ca}^{2+}$ ) decreased the stimulusdependent $\left[\mathrm{Ca}^{2+}\right]_{i}$ rise (38) and enzyme release (39). The signal

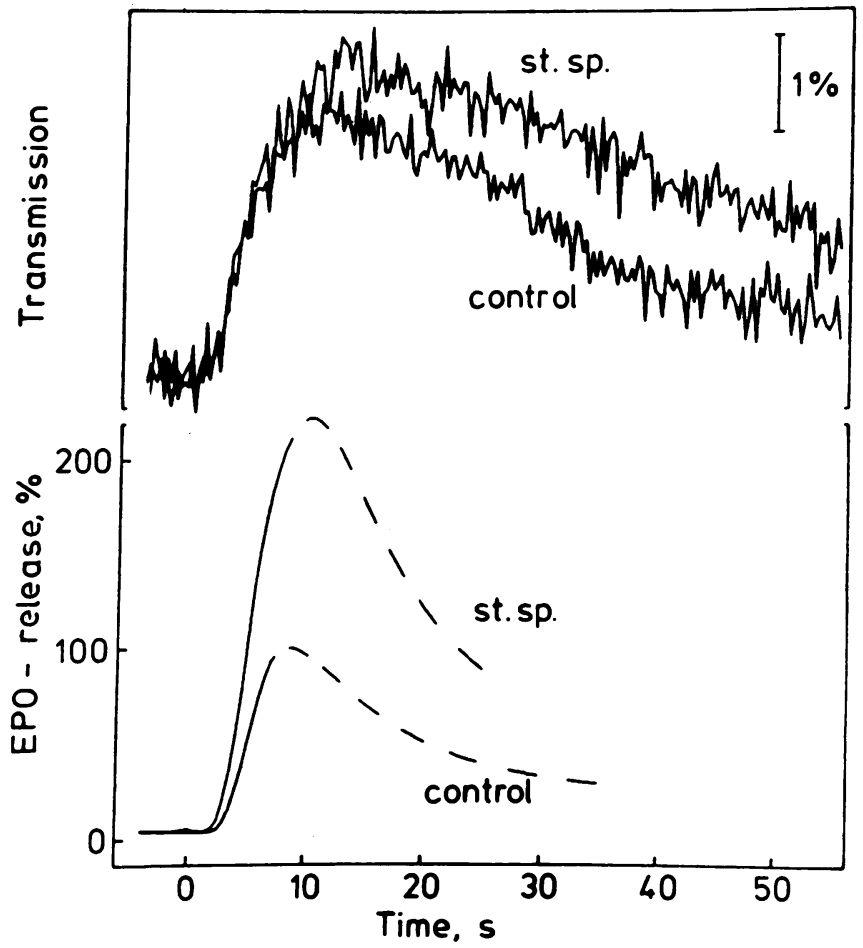

Figure 6. Effect of staurosporine on shape change and EPO release. Normal eosinophils (control) and eosinophils that were pretreated for $1 \mathrm{~min}$ with $100 \mathrm{nM}$ staurosporine (st.sp.) were stimulated with $10 \mathrm{nM}$ C5a. Transmission changes (top) and EPO release-associated chemiluminescence (bottom) are shown. Similar results were obtained with $100 \mathrm{nM}$ PAF.

transduction events leading to these two responses seem to be exclusively dependent on GTP-binding proteins of the $G_{i}$ type.

Agonist-induced exocytosis of EPO in cytochalasin Btreated eosinophils was markedly enhanced by staurosporine. These results are similar to these obtained in neutrophils, where staurosporine by itself induced specific granule release and inhibited PMA- and FMLP-modulated phosphorylation of 48-kD proteins (28). Although staurosporine may have other effects (40-43) including (at high concentrations) inhibition of cyclic nucleotide-dependent kinases (44), it is an effective inhibitor of phospholipid/ $\mathrm{Ca}^{2+}$ dependent protein kinase

Table I. Effect of PMA Pretreatment on C5a-and PAF-induced Changes in Light Transmission and $\left[\mathrm{Ca}^{2+}\right]_{i}$ (Number of Experiments in Parenthesis)*

\begin{tabular}{lccc}
\hline & & & $\begin{array}{c}\text { Statistically } \\
\text { significant } \\
\text { inhibition }\end{array}$ \\
\hline Changes in $\left[\mathrm{Ca}^{2+}\right]_{\mathrm{i}}(n M)$ & Control & PMA & \\
$\quad$ C5a & $660 \pm 360(6)$ & $190 \pm 190(6)$ & yes \\
$\quad$ PAF & $500 \pm 190(5)$ & $150 \pm 150(4)$ & yes \\
Changes in transmission (\%) & & & \\
$\quad$ C5a & $2.2 \pm 0.6(6)$ & $1.9 \pm 0.9(6)$ & no \\
PAF & $2.7 \pm 1.4(7)$ & $0.7 \pm 0.3(4)$ & yes \\
\hline
\end{tabular}

* $8 \times 10^{5}$ eosinophils $/ \mathrm{ml}$, loaded with indo- 1 (see Methods), were pretreated for 2 min with 2-10 nM PMA and stimulated either with $10 \mathrm{nM}$ C $5 \mathrm{a}$ or $100 \mathrm{nM}$ PAF. Data are reported as mean \pm SD. ${ }^{\ddagger}$ Statistically significant inhibition. Paired Student's $t$ test, $P \leqslant 0.05$. 
C (PKC) (45-49). Together with the present results, this indicates, that PKC activity plays a minor role in agonist-induced EPO release, which is in agreement with interpretations based on experiments with $\mathrm{H}-7$ or $\mathrm{C}-1$ in neutrophils (50-52).

The unexpected, staurosporine-dependent increase in EPO release seems to be decoupled from PKC-mediated protein phosphorylation. Interestingly, it has also been reported that staurosporine, like phorbol esters and diacylglycerols, induces the translocation of protein kinase $C$ to membranes (49).

In contrast to the respiratory burst, which was totally inhibited by $100 \mathrm{nM}$ staurosporine (Wymann, M. P., V. von Tscharner, P. C. Tai, C. J. Spry, P. Kernen, and M. Baggiolini, manuscript in preparation), the early phases of PAF- and C5ainduced shape changes were not affected, although the response was slightly prolonged. This further supports the conclusion from $\mathrm{Ca}^{2+}$ depletion experiments, that PKC is not involved in rapid morphologic changes.

A further evidence for a modulation of eosinophil responses by protein kinase $\mathrm{C}$ is provided by the observation that the extent of the $\left[\mathrm{Ca}^{2+}\right]_{i}$ rise induced by $\mathrm{C} 5 \mathrm{a}$ and PAF was decreased by PMA. Downregulating effects of protein kinase $C$ have been observed in other cell types. Phorbol ester or 1,2-diacylglycerol pretreatment of human platelets inhibited the production of inositol phosphates (53), suggesting a feedback control of second messenger generation by protein kinase C. PMAactivated protein kinase $C$ in human neutrophils enhanced diacylglycerol formation through the hydrolysis of a substrate other than phosphatidylinositol 4,5-bisphosphate, e.g., phosphatidylcholine $(29,54)$. Such a switch would decrease $\mathrm{IP}_{3}$ production and reduce the rise in $\left[\mathrm{Ca}^{2+}\right]_{i}$. A possible explanation for reduced $\left[\mathrm{Ca}^{2+}\right]_{i}$ rises in platelets was given by Connolly et al. (55), who observed the activation of an inositol trisphosphate $5^{\prime}$-phosphomonoesterase by protein kinase $C$. The fact that some G-proteins (e.g., the alpha-subunit of transducin or Gprotein coupled to the beta-adrenergic receptor kinase) are conformation-dependent substrates for protein kinase $\mathrm{C}$ suggests that once activated this kinase may have a regulatory effect even on earlier events of the signal transduction sequence (56).

This comparative study shows that PAF and C5a are powerful stimuli for human eosinophils, and that only minor effects are obtained with FMLP and NAP-1/IL-8. PAF, which has been studied most exclusively, is chemotactic for eosinophils from both normal $(57,58)$ and hypereosinophilic individuals (59) and induces the release of EPO and eosinophil cationic protein (39). The low effectiveness of NAP-1/IL-8 on eosinophil shape change activity as compared with neutrophils (37) is in agreement with the observation that despite massive neutrophil accumulation (60), virtually no eosinophils are found after intradermal administration of NAP-1/IL-8 in animals. NAP1/IL-8 also lacks stimulating or priming effects on secretion of eosinophil cationic protein in isolated eosinophils (Tai, P. C., and C. J. Spry, manuscript in preparation), and can thus be ruled out as a mediator of eosinophil diapedesis and function.

While neutrophils respond with similar degree to all four of the stimuli used in this study, the higher agonist selectivity exhibited by eosinophils is likely to determine the type of pathophysiology that is associated with eosinophilia (61). It is well established that eosinophils from patients with HES are more responsive to stimulation than blood eosinophils from normal individuals. They have increased metabolic (62), secretory (63), and cytotoxic capacities $(49,64)$, and are thus similar to tissue eosinophils (65). However, normal blood eosinophils can be primed by cytokines like GM-CSF, IL-3, and IL-5 to acquire the responsiveness of HES eosinophils (66-68). The increased responsiveness and the availability as well as high degree of purity of cells have permitted to obtain reliable comparisons of the effects of different agonists and inhibitory conditions, which are likely to apply to the eosinophil of normal individuals as well.

\section{Acknowledgments}

This work was supported by the Swiss National Science Foundation grants No. 31-25700.88 and 31-25287.88, and the British Heart Foundation, UK.

\section{References}

1. Zucker-Franklin, D. 1974. Eosinophil function and disorders. Adv. Intern. Med. 19:1-25.

2. Gleich, G. J., and C. R. Adolphson. 1986. The eosinophilic leukocyte: structure and function. Adv. Immunol. 39:177-253.

3. Spry, C. J. 1988. Eosinophils in disease. In Eosinophils. A Comprehensive Review, and Guide to the Scientific and Medical Literature. C. J. Spry, editor. Oxford University Press, Oxford. 131-317.

4. Spry, C. J., and P. C. Tai. 1989. Eosinophils and tissue injury. In Eosinophils in Asthma. Perspectives in Asthma. J: Morley and I. Colditz, editors. 4. Academic Press Limited (AP), London. 185-193.

5. Tai, P. C., and C. J. Spry. 1990. Eosinophil effector mechanisms: studies on the ways in which eosinophils induce endomyocardial fibrosis. In Restrictive and electric disturbances in heart muscle diseases. Cardiomyopathy Update. M. Sekiguchi, editor. University of Tokyo Press, Tokyo. 99-107.

6. Rosenberg, H. F., S. J. Ackerman, and D. G. Tenen. 1989. Human eosinophil cationic protein. Molecular cloning of a cytotoxin and helminthotoxin with ribonuclease activity. J. Exp. Med. 170:163-176.

7. Rosenberg H. F, D. G. Tenen, and S. J. Ackerman. 1989. Molecular cloning of the human eosinophil-derived neurotoxin: a member of the ribonuclease gene family. Proc. Natl. Acad. Sci. USA. 86:4460-4464.

8. Ten, R. M., L. R. Pease, D. J. McKean, M. P. Bell, and G. J. Gleich. 1989 Molecular cloning of the human eosinophil peroxidase. Evidence for the existence of a peroxidase multigene family. J. Exp. Med. 169:1757-1769.

9. Barker, R. L., G. J. Gleich, and L. R. Pease. 1988. Acidic precursor revealed in human eosinophil granule major basic protein cDNA. J. Exp. Med. 168:1493 1498. (Published erratum appears in 1989. J. Exp. Med. 170:1057.)

10. Sanderson, C. J. 1988. Interleukin-5: an eosinophil growth and activation factor. Dev. Biol. Stand. 69:23-29.

11. Klebanoff, S. J., D. T. Durack, H. Rosen, and R. A. Clark. 1977. Functional studies on human peritoneal eosinophils. Infect. Immun. 17:167-173.

12. Anwar, A. R., and A. B. Kay. 1977. The ECF-A tetrapeptides and histamine selectively enhance human eosinophil complement receptors. Nature (Lond.). 269:522-524.

13. Baggiolini, M., and B. Dewald. 1988. Cellular models for the detection and evaluation of drugs that modulate human phagocyte activity. Experientia. 44:841-848.

14. Dillon, S. B., M. W. Verghese, and R. Snyderman. 1988. Signal transduction in cells following binding of chemoattractants to membrane receptors. Virchows. Arch. B Cell Pathol. 55:65-80.

15. Omann, G. M., R. A. Allen, G. M. Bokoch, R. G. Painter, A. E. Traynor, and L. A. Sklar. 1987. Signal transduction and cytoskeletal activation in the neutrophil. Physiol. Rev. 67:285-322

16. Lackie, J. M. 1988. The behavioural repertoire of neutrophils requires multiple signal transduction pathways. J. Cell Sci. 89:449-452.

17. Baggiolini, M., A. Walz, and S. L. Kunkel. 1989. Neutrophil-activating peptide-1/interleukin 8 , a novel cytokine that activates neutrophils. J. Clin. In vest. 84:1045-1049.

18. Wymann, M. P., V. von Tscharner, D. A. Deranleau, and M. Baggiolini. 1987. The onset of the respiratory burst in human neutrophils. Real-time studies of $\mathrm{H}_{2} \mathrm{O}_{2}$ formation reveal a rapid agonist-induced transduction process. J. Biol. Chem. 262:12048-12053.

19. Lindley, I, H. Aschauer, J. M. Seifert C. Lam, W. Brunowsky, E. Kownatzki, M. Thelen, P. Peveri, B. Dewald, V. von Tscharner, A. Walz, and M. Baggiolini. 1988. Synthesis and expression in Escherichia coli of the gene encoding monocyte-derived neutrophil-activating factor: biological equivalence between natural and recombinant neutrophil-activating factor. Proc. Natl. Acad. Sci. USA. 85:9199-9203.

20. Hugli, T. E., C. Gerard, M. Kawahara, M. E. Scheetz, R. Barton, S. Briggs, G. Koppel, and S. Russell. 1981. Isolation of three separate anaphylatoxins from complement-activated human serum. Mol. Cell. Biochem. 41:59-66.

21. Vadas, M. A., J. R. David, A. Butterworth, N. T. Pisani, and T. A. Siongok. 1979. A new method for the purification of human eosinophils and neutro- 
phils, and a comparison of the ability of these cells to damage schistosomula of Schistosoma mansoni. J. Immunol. 122:1228-1236.

22. Tai, P. C., D. M. Bakes, J. R. Barkans, and C. J. Spry. 1985. Plasma membrane antigens on light density and activated human blood eosinophils Clin. Exp. Immunol. 60:427-436.

23. Wymann, M. P., P. Kernen, D. A. Deranleau, B. Dewald, V. von Tscharner, and M. Baggiolini. 1987. Oscillatory motion in human neutrophils responding to chemotactic stimuli. Biochem. Biophys. Res. Commun. 147:361368.

24. Deranleau, D. A., and E. Stuessi. 1987. Repetitive subsecond fluorescence spectra and anisotropy measurements using an optical multichannel analyzer. Rev. Sci. Instrum. 58:1840-1842.

25. Grynkiewicz, G., M. Poenie, and R. Y. Tsien. 1985. A new generation of $\mathrm{Ca}^{2+}$ indicators with greatly improved fluorescence properties. J. Biol. Chem 260:3440-3450.

26. Carlson, M. G., C. G. Peterson, and P. Venge. 1985. Human eosinophil peroxidase: purification and characterization. J. Immunol. 134:1875-1879.

27. Thorpe, G. H., and L. J. Kricka. 1986. Enhanced chemiluminescent reactions catalyzed by horseradish peroxidase. Methods Enzymol. 133:331-353.

28. Dewald, B., M. Thelen, M. P. Wymann, and M. Baggiolini. 1989. Staurosporine inhibits the respiratory burst and induces exocytosis in human neutrophils. Biochem. J. 264:879-884.

29. Tyagi, S. R., M. Tamura, D. N. Burnham, and J. D. Lambeth. 1988. Phorbol myristate acetate (PMA) augments chemoattractant-induced diglyceride generation in human neutrophils but inhibits phosphoinositide hydrolysis. Implications for the mechanism of PMA priming of the respiratory burst. J. Biol. Chem. 263:13191-13198. (Published erratum appears in 1989. J. Biol. Chem. 264:1901).

30. Smith, R. J., J. M. Justen, and L. M. Sam. 1988. Function and stimulusspecific effects of phorbol 12-myristate 13-acetate on human polymorphonuclear neutrophils: autoregulatory role for protein kinase $\mathrm{C}$ in signal transduction. Inflammation. 12:597-611.

31. Verghese, M. W., L. Charles, L. Jakoi, S. B. Dillon, and R. Snyderman. 1987. Role of a guanine nucleotide regulatory protein in the activation of phospholipase $C$ by different chemoattractants. $J$. Immunol 138:4374-4380.

32. Deranleau, D. A. 1988. Real-time models of morphogenetic processes. Experientia. 44:679-684.

33. Wymann, M. P., P. Kernen, T. Bengtsson, T. Andersson, M. Baggiolini, and D. A. Deranleau. 1990. Corresponding oscillations in neutrophil shape and filamentous actin content. J. Biol. Chem. 265:619-622.

34. Wymann, M. P., P. Kernen, D. A. Deranleau, and M. Baggiolini. 1989. Respiratory burst oscillations in human neutrophils and their correlation with fluctuations in apparent cell shape. J. Biol. Chem. 264:15829-15834

35. Grzeskowiak, M., V. Della Bianca, M. A. Cassatella, and F. Rossi. 1986. Complete dissociation between the activation of phosphoinositide turnover and of NADPH oxidase by formyl-methionyl-leucyl-phenylalanine in human neutrophils depleted of $\mathrm{Ca}^{2+}$ and primed by subthreshold doses of phorbol 12, myristate 13, acetate. Biochem. Biophys. Res. Commun. 135:785-794.

36. Bengtsson, T., I. Rundquist, O. Stendahl, M. P. Wymann, and T. Andersson. 1988. Increased breakdown of phosphatidylinositol 4,5-bisphosphate is not an initiating factor for actin assembly in human neutrophils. J. Biol. Chem. 263:17385-17389.

37. Thelen, M., P. Peveri, P. Kernen, V. von Tscharner, A. Walz, and M. Baggiolini. 1988. Mechanism of neutrophil activation by NAF, a novel monocyte-derived peptide agonist. FASEB (Fed. Am. Soc. Exp. Biol.) J. 2:2702-2706.

38. Kroegel, C., R. Pleass, T. Yukawa, K. F. Chung, J. Westwick, and P. J. Barnes. 1989. Characterization of platelet-activating factor-induced elevation of cytosolic free calcium concentration in eosinophils. FEBS (Fed. Eur. Biol. Soc.) Lett. 243:41-46.

39. Kroegel, C., T. Yukawa, G. Dent, P. Venge, K. F. Chung and P. J. Barnes 1989. Stimulation of degranulation from human eosinophils by platelet-activating factor. J. Immunol. 142:3518-3526.

40. Badwey, J. A., W. Horn, P. G. Heyworth, J. M. Robinson, and M. L. Karnovsky. 1989. Paradoxical effects of retinal in neutrophil stimulation. J. Biol. Chem. 264:14947-14953.

41. Hockberger, P., M. Toselli, D. Swandulla and H. D. Lux. 1989. A diacylglycerol analogue reduces neuronal calcium currents independently of protein kinase C activation. Nature (Lond.). 338:340-342.

42. Robinson, J. M., P. G. Heyworth, and J. A. Badwey. 1990. Utility of staurosporine in uncovering differences in the signal transduction pathways for superoxide production in neutrophils. Biochim. Biophys. Acta. 1055:55-62.

43. Taylor, D. J., J. M. Evanson, and D. E. Woolley. 1990. Contrasting effects of the protein kinase $\mathrm{C}$ inhibitor, staurosporine, on cytokine and phorbol ester stimulation of fructose 2,6-bisphosphate and prostaglandin $\mathrm{E}$ production by fibroblasts in vitro. Biochem. J. 269:573-577.

44. Kase, H., K. Iwahashi, and Y. Matsuda. 1986. K-252b, c and d, potent inhibitors of protein kinase C from microbial origin. J. Antibiot. 36:1059-1065.

45. Tamaoki, T., H. Nomoto, I. Takahashi, Y. Kato, M. Morimoto, and F.
Tomita. 1986. Staurosporine, a potent inhibitor of phospholipid/Ca ++ dependent protein kinase. Biochem. Biophys. Res. Commun. 135:397-402.

46. Kiyoto, I., S. Yamamoto, E. Aizu, and R. Kato. 1987. Staurosporine, a potent protein kinase $C$ inhibitor, fails to inhibit 12-O-tetradecanoylphorbol-13-acetate-caused ornithine decarboxylase induction in isolated mouse epidermal cells. Biochem. Biophys. Res. Commun. 148:740-746.

47. Nakadate, T., A. Y. Jeng, and P. M. Blumberg. 1988. Comparison of protein kinase $C$ functional assays to clarify mechanisms of inhibitor action. Biochem. Pharmacol. 37:1541-1545.

48. Vegesna, R. V., H. L. Wu, S. Mong, and S. T. Crooke. 1988. Staurosporine inhibits protein kinase $C$ and prevents phorbol ester-mediated leukotriene D4 receptor desensitization in RBL-1 cells. Mol. Pharmacol. 33:537-542.

49. Wolf, M., and M. Baggiolini. 1988. The protein kinase inhibitor staurosporine, like phorbol esters, induces the association of protein kinase $\mathrm{C}$ with membranes. Biochem. Biophys. Res. Commun. 154:1273-1279.

50. Berkow, R. L., R. W. Dodson, and A. S. Kraft. 1987. The effect of a protein kinase $\mathrm{C}$ inhibitor, $\mathrm{H}-7$, on human neutrophil oxidative burst and degranulation. J. Leukocyte. Biol. 41:441-446.

51. Salzer, W., C. Gerard, and C. McCall. 1987. Effect of an inhibitor of protein kinase $\mathrm{C}$ on human polymorphonuclear leukocyte degranulation. Bio chem. Biophys. Res. Commun. 148:747-754.

52. Sha'afi, R. I., T. F. Molski, J. Gomez Cambronero, and C. K. Huang. 1988. Dissociation of the 47-kilodalton protein phosphorylation from degranulation and superoxide production in neutrophils. J. Leukocyte Biol. 43:18-27.

53. Watson, S. P., and E. G. Lapetina. 1985. 1,2-Diacylglycerol and phorbol ester inhibit agonist-induced formation of inositol phosphates in human platelets: possible implications for negative feedback regulation of inositol phospholipid hydrolysis. Proc. Natl. Acad. Sci. USA. 82:2623-2626.

54. Fällman, M., O. Stendahl, and T. Andersson. 1989. Phorbol ester-induced activation of protein kinase $\mathrm{C}$ leads to increased formation of diacylglycerol in human neutrophils. Exp. Cell Res. 181:217-225.

55. Connolly, T. M., W. J. Jr. Lawing, and P. W. Majerus. 1986. Protein kinase $\mathrm{C}$ phosphorylates human platelet inositol trisphosphate $5^{\prime}$-phosphomonoesterase, increasing the phosphatase activity. Cell. 46:951-958.

56. Sagi-Eisenberg, R. 1989. GTP-binding proteins as possible targets for protein kinase C action. Trends Biochem. Sci. 14:355-357.

57. Tamura, N., D. K. Agrawal, F. A. Suliaman, and R. G. Townley. 1987. Effects of platelet activating factor on the chemotaxis of normodense eosinophils from normal subjects. Biochem. Biophys. Res. Commun. 142:638-644.

58. Sigal, C. E., F. H. Valone, M. J. Holtzman, and E. J. Goetzl. 1987. Preferential human eosinophil chemotactic activity of the platelet-activating factor (PAF) 1-0-hexadecyl-2-acetyl-sn-glyceryl-3-phosphocholine (AGEPC). J. Clin. Immunol. 7:179-184.

59. Wardlaw, A. J., R. Moqbel, O. Cromwell, and A. B. Kay. 1986. Plateletactivating factor. A potent chemotactic and chemokinetic factor for human eosinophils. J. Clin. Invest. 78:1701-1706.

60. Colditz, I., R. Zwahlen, B. Dewald, and M. Baggiolini. 1989. In vivo inflammatory activity of neutrophil-activating factor, a novel chemotactic peptide derived from human monocytes. Am. J. Pathol. 134:755-760.

61. Spry, C. J., and P. C. Tai. 1988. Mechanisms of eosinophil induced tissue damage. In Eosinophils in Allgengy and Clinical Immunology. A. L. de Weck and T. Miyamoto, editors. Standard McIntyre, Tokyo. 100-105.

62. Prin, L., J. Charon, M. Capron, P. Gosset, H. Taelman, A. B. Tonnel, and A. Capron. 1984. Heterogeneity of human eosinophils. II. Variability of respiratory burst activity related to cell density. Clin. Exp. Immunol. 57:735-742.

63. Tai, P. C., M. Capron, D. M. Bakes, J. Barkans, and C. J. Spry. 1986 Monoclonal antibodies to human eosinophil plasma membrane antigens enhance the secretion of eosinophil cationic protein. Clin. Exp. Immunol. 63:728737.

64. Prin, L., M. Capron, A. B. Tonnel, O. Bletry, and A. Capron. 1983. Heterogeneity of human peripheral blood eosinophils: variability in cell density and cytotoxic ability in relation to the level and the origin of hypereosinophilia Int. Arch. Allergy. Appl. Immunol. 72:336-346.

65. Capron, M., J. P. Kusnierz, L. Prin, H. L. Spiegelberg, J. Khalife, A. B. Tonnel, and A. Capron. 1985. Cytophilic IgE on human blood and tissue eosinophils. Int. Arch. Allergy. Appl. Immunol. 77:246-248.

66. Owen, W. F., Jr., M. E. Rothenberg, D. S. Silberstein, J. C. Gasson, R. L. Stevens, K. F. Austen, and R. J. Soberman. 1987. Regulation of human eosinophil viability, density, and function by granulocyte/macrophage colony-stimulating factor in the presence of 3T3 fibroblasts. J. Exp. Med. 166:129-141.

67. Rothenberg, M. E., W. F. Owen, Jr., D. S. Silberstein, J. Woods, R. J. Soberman, K. F. Austen, and R. L. Stevens. 1988. Human eosinophils have prolonged survival, enhanced functional properties, and become hypodense when exposed to human interleukin 3. J. Clin. Invest. 81:1986-1992.

68. Rothenberg M. E., J. Petersen, R. L. Stevens, D. S. Silberstein, D. T. McKenzie, K. F. Austen, and W. F. Owen, Jr. 1989. IL-5-dependent conversion of normodense human eosinophils to the hypodense phenotype uses 3T3 fibroblasts for enhanced viability, accelerated hypodensity, and sustained antibodydependent cytotoxicity. J. Immunol. 143:2311-2316. 